\title{
On the transformation mechanism of $\mathrm{K}_{2} \mathrm{Ti}_{4} \mathrm{O}_{9}$ to $\mathrm{TiO}_{2}(\mathrm{~B})$ and formation of microvoids
}

L. Reine Wallenberg $\left({ }^{1}\right)$, Mehri Sanati $\left({ }^{2}\right)$ and Arne Andersson $\left({ }^{2}\right)$

( $\left.{ }^{1}\right)$ National Center for HREM, Inorganic Chemistry 2, Lund University, Box 124, 22100 Lund, Sweden

(2) Department of Chemical Technology Chemical Center, Lund University, Box 124, 22100 Lund, Sweden

(Received October 24, 1990; accepted February 12, 1991)

\begin{abstract}
Résumé. - $\mathrm{TiO}_{2}(\mathrm{~B})$, potentiellement support de catalyseur, a été préparé à partir d'un précurseur $\mathrm{K}_{2} \mathrm{Ti}_{4} \mathrm{O}_{9}$. La microscopie électronique haute résolution a revélé que la perte en volume de $32 \%$ lors de la transformation est compensée par la formation de microcavités, d'une taille moyenne de $10 \mathrm{~nm}$, ce qui préserve la morphologie et la forme du cristal original. Un mécanisme structural, proposant une structure pour un intermédiaire $\mathrm{K}_{2} \mathrm{Ti}_{2} \mathrm{O}_{5}$, est suggéré.
\end{abstract}

\begin{abstract}
TiO}_{2}(\mathrm{~B})$, a potential catalyst support, has been synthesized from a support precursor, $\mathrm{K}_{2} \mathrm{Ti}_{4} \mathrm{O}_{9}$. High resolution electron microscopy revealed that the $32 \%$ volume loss in this transformation is achieved by formation of facetted microvoids, around $10 \mathrm{~nm}$ in size, maintaining the morphology and size of the original crystals, A structural mechanism, including a hypothetical structure for a $\mathrm{K}_{2} \mathrm{Ti}_{2} \mathrm{O}_{5}$ intermediate, is suggested.
\end{abstract}

\section{Introduction.}

1.1 Catalysis. - Titanium dioxide is a commonly used support for catalysts, usually in the form of rutile or anatase. Anatase is often preferred, in part because of its higher specific surface area (approx. $50 \mathrm{~m}^{2} / \mathrm{g}$ ) as compared to rutile (approx. $10 \mathrm{~m}^{2} / \mathrm{g}$ ).

Recently it was discovered that a new form of titanium dioxide, $\mathrm{TiO}_{2}$ (B) [1], could actually improve the catalytic performance of a vanadium oxide catalyst used in an ammoxidation reaction [2]. A maximum conversion rate per unit surface area, 2-3 times as high as that of pure $\mathrm{V}_{2} \mathrm{O}_{5}$ was found for a catalyst with a loading corresponding to 1.5 theoretical monolayers of $\mathrm{V}_{2} \mathrm{O}_{5}$ on the $\mathrm{TiO}_{2}$ (B) support. Additional layers decreased the activity, eventually approaching that of pure $\mathrm{V}_{2} \mathrm{O}_{5}$ for a loading in excess of 10 monolayers.

$\mathrm{TiO}_{2}$ (B) can be prepared by first hydrolyzing a support precursor, $\mathrm{K}_{2} \mathrm{Ti}_{4} \mathrm{O}_{9}$, in excess of nitric acid, which completely removes the potassium from the tetratitanate [3]. Then the intermediate 
obtained is calcined in air at $500^{\circ} \mathrm{C}$. The present work concerns the mechanism of this transformation.

1.2 STRUCTURES. - Titanium and vanadium are very similar in their appearance in oxides and alkali metal oxides, and several common structure building units can be found.

The structure of $\mathrm{TiO}_{2}(\mathrm{~B})$ is isotypic with the bronze $\mathrm{Na}_{x} \mathrm{Ti}_{4} \mathrm{O}_{8}(x=0.8)$ described by Andersson and Wadsley [4]. In figure 1 is shown a sphere model, projected along the $b$-axis, where the distorted octahedra units are indicated. Coordinates predicted by energy minimization techniques [5], have been used to construct the model. In the bronze, the sodium partly occupies the tunnels marked by " $A$ ". The distorsion found in the octahedral sheets of $\mathrm{Na}_{x} \mathrm{Ti}_{4} \mathrm{O}_{8}$ is of the same type as in the bronze $\mathrm{Ag}_{x} \mathrm{~V}_{2} \mathrm{O}_{5}(x=0.68)$ [6].

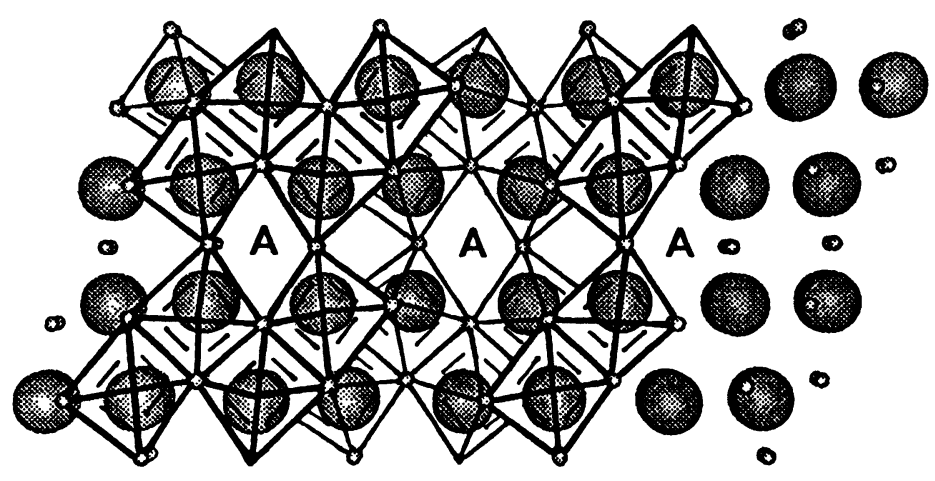

Fig. 1. - Sphere model of $\mathrm{TiO}_{2}(\mathrm{~B})$, based on coordinates predicted by energy minimization techniques. Large spheres are $\mathrm{Ti}$, and small spheres $\mathrm{O}$. The distorted octahedral framework is indicated. (010) projection. "A" indicates sites for sodium in $\mathrm{Na}_{x} \mathrm{Ti}_{4} \mathrm{O}_{8} .2 \times 2$ unit cells are shown.

The titanium-oxygen framework may be described as double zig-zag ribbons of octahedra having common edges, the ribbons joining corners to form a sheet parallel to the $b-c$ plane. The same type of sheets, but with the double ribbons replaced by triple ribbons, has been found in, e.g., $\mathrm{Na}_{2} \mathrm{Ti}_{3} \mathrm{O}_{7}$ and $\mathrm{Na}_{2} \mathrm{Ti}_{6} \mathrm{O}_{13}$ [7], and quadruple ribbons in, e.g., $\mathrm{Tl}_{2} \mathrm{Ti}_{4} \mathrm{O}_{9}$ [6].

The layers are connected by edge sharing with alternately reversed layers to form the $\mathrm{TiO}_{2}(\mathrm{~B})$ structure. This forms an $\mathrm{AX}_{2}$-type framework that cannot be found in the polymorphs rutile, anatase or brookite. $\mathrm{TiO}_{2}(\mathrm{~B})$ transforms into anatase at $550^{\circ} \mathrm{C}$ under normal pressure [9].

An isotypic vanadium oxide, $\mathrm{VO}_{2}(\mathrm{~B})$ has been reported [10].

$\mathrm{TiO}_{2}(\mathrm{~B})$ is reported as monoclinic, space group $C 2 / m$ with $a=1.2163 \mathrm{~nm}, b=0.373 \mathrm{~nm}, c=$ $0.651 \mathrm{~nm}$, and $\beta=107.3^{\circ}$.

The support precursor, $\mathrm{K}_{2} \mathrm{Ti}_{4} \mathrm{O}_{9}$, belongs to a family of isostructural tetratitanates, $M_{2} \mathrm{Ti}_{4} \mathrm{O}_{9}$ where $M=\mathrm{Li}, \mathrm{Na}, \mathrm{K}, \mathrm{Rb}, \mathrm{Cs}, \mathrm{Ag}$ or $\mathrm{Tl}[11]$, and is reported as monoclinic, $C 2 / m, Z=4$, with $a=1.825 \mathrm{~nm}, b=0.379 \mathrm{~nm}, c=1.201 \mathrm{~nm}, \beta=106.4^{\circ}$. A sphere model of the structure, projected along the shortest axis $(b)$, is shown in figure 2 . It is a layered structure, where the layers consist of quadruple zig-zag ribbons of octahedra joined together by sharing corners. The layers are separated by potassium ions. 


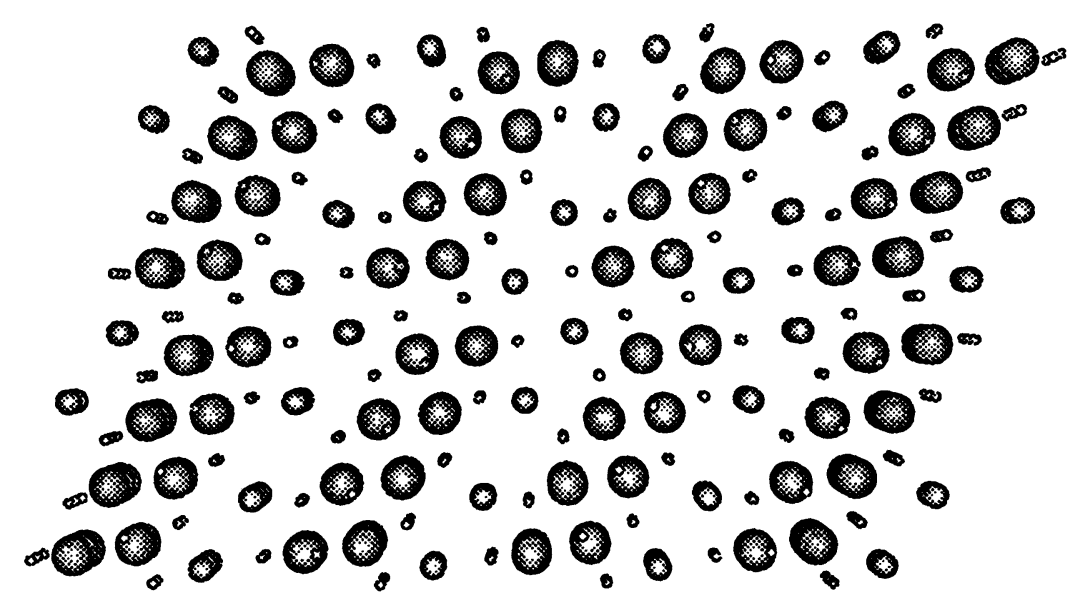

Fig. 2. - Sphere model of $\mathrm{K}_{2} \mathrm{Ti}_{4} \mathrm{O}_{9}$. Large spheres $=\mathrm{Ti}$, medium $=\mathrm{K}$ and small $=0.2 \times 2$ unit cells are shown. (010) projection.

\section{Experimental.}

Support precursors were prepared by mixing amounts of $\mathrm{KNO}_{3}$ and $\mathrm{TiO}_{2}$ (anatase), in proportions $\mathrm{K} / \mathrm{Ti}=0.5-1.8$, and calcining in air at $950^{\circ} \mathrm{C}$ for $44 \mathrm{~h}$. A slight excess of potassium nitrate was found necessary to form the wanted tetratitanates. The product was ground and hydrolyzed by $0.45 \mathrm{M} \mathrm{HNO}_{3}$ for three days, followed by calcination in air at $500^{\circ} \mathrm{C}$ to produce the final $\mathrm{TiO}_{2}(\mathrm{~B})$ support.

Characterization of the precursor and the support was performed by several techniques, e.g. scanning electron microscopy (SEM), high resolution transmission electron microscopy (HREM), energy dispersive $x$-ray spectroscopy (EDS), BET surface area determination and x-ray powder diffraction $[12,13]$. The intermediate phase, obtained after hydrolysis but before calcination, was investigated by HREM.

SEM and quantitative analysis were performed with a JEM 840A microscope, equipped with a LINK AN 10000 energy dispersive spectrometer. HREM images and electron diffraction patterns were recorded on a JEM $4000 \mathrm{EX}$ microscope, capable of $0.16 \mathrm{~nm}$ point resolution at $400 \mathrm{kV}$ in projected crystal structures.

The zone axis orientation of imaged crystals was verified by simulated electron diffraction patterns and real structure projection plots, produced by the EMS computer program suite (P. Stadelmann). Due to the small particle size, which at times made recording of selected area electron diffraction patterns difficult, phase and zone axis determinations were further verified by optical diffraction of recorded HREM images.

\section{Results.}

3.1 SUPPORT PRECURSOR - X-ray powder diffraction of the support precursor obtained from a mixture of $\mathrm{KNO}_{3}$ and anatase with an initial K/Ti atomic ratio of 0.6 showed only lines corresponding to $\mathrm{K}_{2} \mathrm{Ti}_{4} \mathrm{O}_{9}$. However, on investigation with SEM, two different phases were easily distinguishable through their different morphology (cf. Fig. 3). The major phase consisted of 


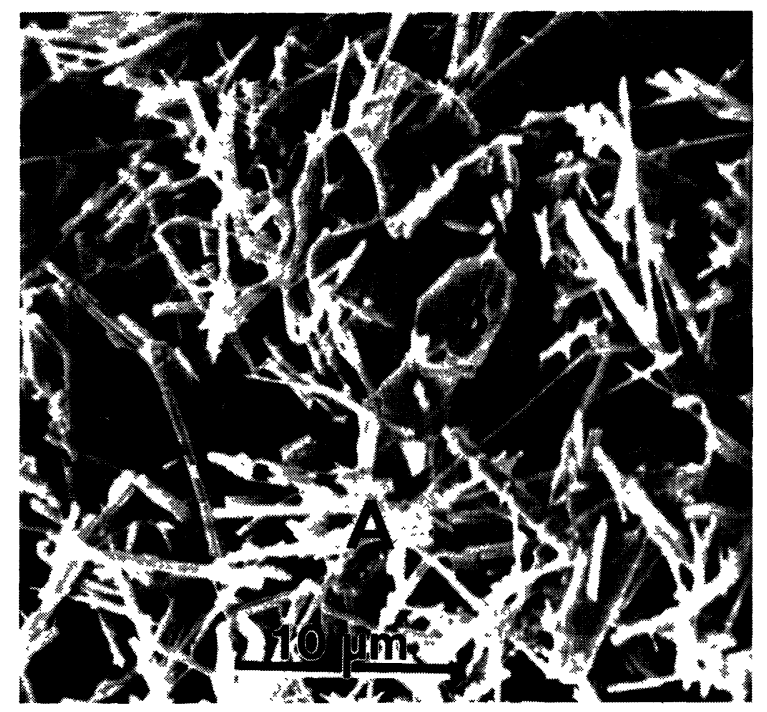

Fig. 3. - Scanning electron micrograph of the support precursor with initial ratio $\mathrm{K} / \mathrm{Ti}=0.6$. The rodlike particles, (A), showed a ratio $\mathrm{K} / \mathrm{Ti}=0.5$, thus corresponding to $\mathrm{K}_{2} \mathrm{Ti}_{4} \mathrm{O}_{9}$. The minor phase, (B), had a $\mathrm{K} / \mathrm{Ti}$ ratio of approx. 1.0, suggesting $\mathrm{K}_{2} \mathrm{Ti}_{2} \mathrm{O}_{5}$.

extremely rodlike particles with typical dimensions being $0.2 \times 0.2 \times 8.0 \mu \mathrm{m}$. The minor phase appeared as larger, smoother particles. The specific surface area was $4-5 \mathrm{~m}^{2} / \mathrm{g}$.

EDS analysis of the elemental composition of the two phases established the rodlike particles to be $\mathrm{K}_{2} \mathrm{Ti}_{4} \mathrm{O}_{9}$, based on the $\mathrm{Ti} / \mathrm{K}$ ratio always being in the interval 1.9-2.1. The larger, smoother particles showed a greater variation, and could in places vary between 1.0-3.2. However, larger, homogeneous parts were $\mathrm{K}_{2} \mathrm{Ti}_{2} \mathrm{O}_{5}$ according to the measured $\mathrm{Ti} / \mathrm{K}$ ratio being close to unity.

HREM imaging of $\mathrm{K}_{2} \mathrm{Ti}_{4} \mathrm{O}_{9}$, showed the rodlike particles to consist of bundles of very narrow, intergrown single crystals, having the shortest axis $(b=0.379 \mathrm{~nm})$ always oriented along the long axis of the rod. The crystals were quite stable in the beam, and contained very few defects, except towards the end of the rods, where some splitting occured (Fig. 4).

The large smooth particles generally were too thick for HREM imaging, but seemed to be of less crystallinity and were more sensitive to exposure by the electron beam.

3.2 $\mathrm{TiO}_{2}(\mathrm{~B})$ sUPPORT. - After hydrolysis with nitric acid and calcining in air, the $\mathrm{TiO}_{2}(\mathrm{~B})$ particles were seen to be isomorphous with the $\mathrm{K}_{2} \mathrm{Ti}_{4} \mathrm{O}_{9}$ precursor, and with no change in size distribution, when examined by SEM. This is rather surprising, since with the ultimate removal of $\mathrm{K}_{2} \mathrm{O}$ from the structure, approximately $32 \%$ of the volume is lost, as calculated from the unit cell parameters and cell content. The measured density has previously been found to be substantially lower than the expected value [3].

HREM images showed that the volume loss is achieved by formation of a large number of facetted microvoids, sometimes referred to as "negative crystals", or "mosaic" crystals [3], throughout the bulk of the material (Fig. 5). The microvoids were present already at low-dose images recorded of unexposed areas by an image intensified TV-camera, and did not change in size or distribution upon prolonged exposure to a fully converged beam $[12,13]$. Thus, the voids are not formed through beam damage.

High resolution stereo images and BET surface area measurement confirmed that the voids are 


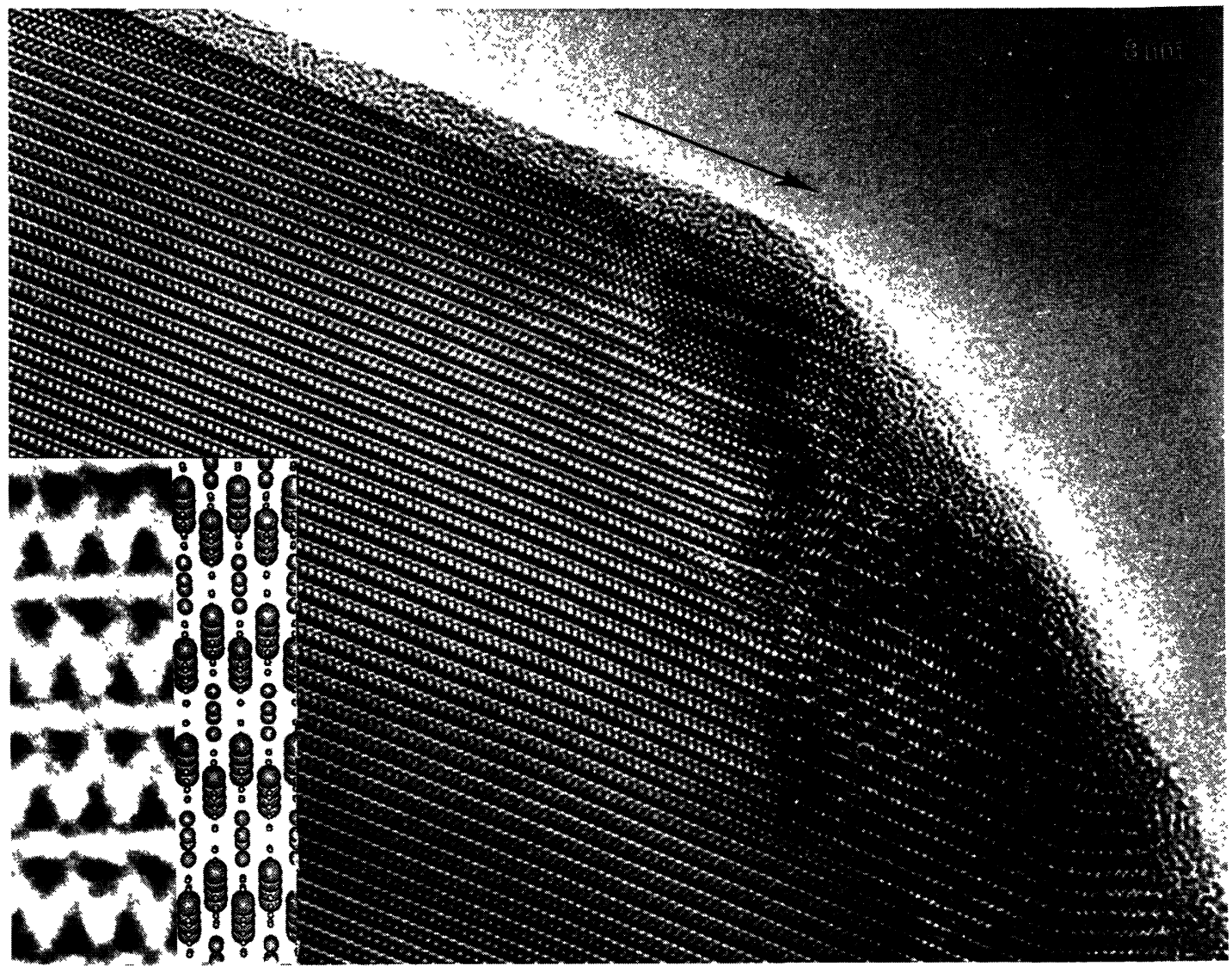

Fig. 4. - High resolution image of a $\mathrm{K}_{2} \mathrm{Ti}_{4} \mathrm{O}_{9}$ rod in the (001) zone axis orientation. The rod is single crystalline, apart for some splitting toward the end. The direction of the long axis of the rod (which is parallel to the $b$-axis) is indicated by the arrow. The inset shows an enlarged part of the image compared to a sphere model of the structure. The radius of the drawn Ti atoms (large spheres) was chosen as $0.08 \mathrm{~nm}$, so as to correspond to the resolution limit of the microscope. Medium sized spheres are potassium and small spheres are oxygen. Each dark patch corresponds to four unresolved atom columns.

mostly formed in the bulk of the material [13], and, as such, are inaccessible to catalytic events. The specific surface area was $14 \mathrm{~m}^{2} / \mathrm{g}$, which is intermediate for catalyst supports.

The final product, according to powder $\mathrm{x}$-ray diffraction, was pure $\mathrm{TiO}_{2}(\mathrm{~B})$. EDS analysis showed the residual potassium to be less than 0.7 at- $\%$.

3.3 CONTROLLING MICROVOID FORMATION. - Since the microvoids are formed by removing $\mathrm{K}_{2} \mathrm{O}$ from the $\mathrm{K}_{2} \mathrm{Ti}_{4} \mathrm{O}_{9}$ structure, it is reasonable to assume that an increase in the initial $\mathrm{K} / \mathrm{Ti}$ ratio would enlarge or increase the number of voids. It would thus be possible to achieve an increased specific surface area of the catalyst support by forming connecting channels in the material. In an attempt to do this, the starting composition was varied. The results are summarized in figure 6.

For an initial ratio of $\mathrm{K} / \mathrm{Ti}=0.5$ or less, the formed intermediate could not be further hydrolyzed to $\mathrm{TiO}_{2}(\mathrm{~B})$. The workable range was found to be within a $\mathrm{K} / \mathrm{Ti}$ ratio of $0.6-0.75$. At the low end, the intermediate was almost pure $\mathrm{K}_{2} \mathrm{Ti}_{4} \mathrm{O}_{9}$, with only traces of $\mathrm{K}_{2} \mathrm{Ti}_{2} \mathrm{O}_{5}$ as shown by SEM/EDS. 


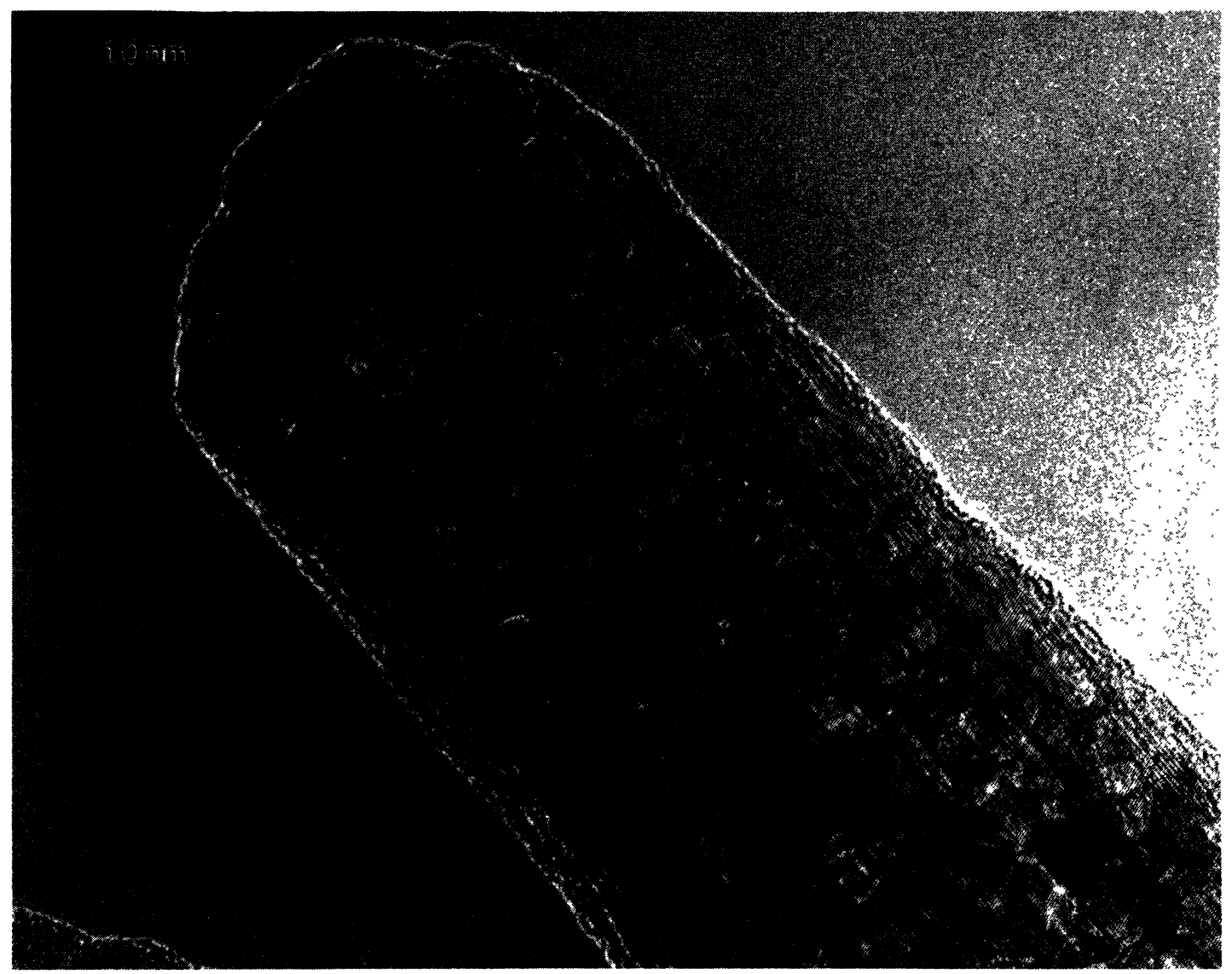

Fig. 5. - $\mathrm{TiO}_{2}$ (B) crystal imaged by HREM. A large defocus value has been used to enhance the microvoids, but the basic lattice is still visible. The short $b$-axis $(0.373 \mathrm{~nm})$ is maintained along the long axis of the rod, when transforming from the support precursor.

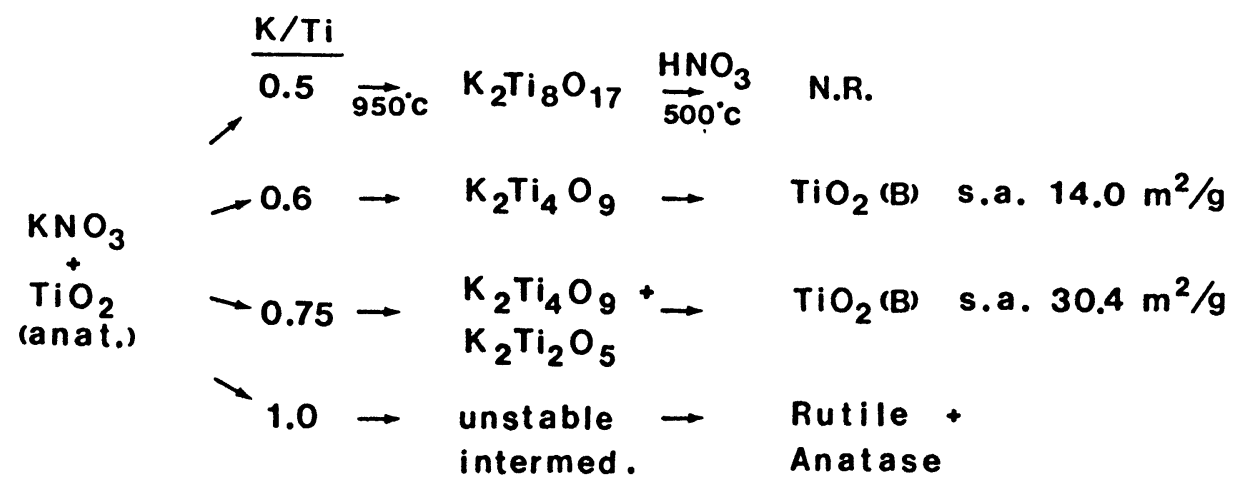

Fig. 6. - Intermediates, identified by $\mathrm{x}$-ray powder diffraction, and resulting surface areas as a function of the initial $\mathrm{K} / \mathrm{Ti}$ ratio of the $\mathrm{KNO}_{3}$ / anatase mixture. N.R.= No Reaction; s.a.= specific area. 
For an increasing K/Ti ratio, the proportion of $\mathrm{K}_{2} \mathrm{Ti}_{2} \mathrm{O}_{5}$ increased.

The accessible surface area could in this way be increased to more than $30 \mathrm{~m}^{2} / \mathrm{g}$, which is quite acceptable for industrial use. Pore size distributions, derived from the BET adsorption isotherms, still showed a sharp maximum for approx. $4.0 \mathrm{~nm}$, indicating that the increased area is achieved by formation of interconnecting channels [14].

$3.4 \mathrm{~K}_{2} \mathrm{Ti}_{2} \mathrm{O}_{5}$. - It has long been known that a phase with the composition $\mathrm{K}_{2} \mathrm{Ti}_{2} \mathrm{O}_{5}$ can be synthesized from melts of $\mathrm{TiO}_{2}$ and $\mathrm{K}_{2} \mathrm{CO}_{3}$ [15]. A homologous composition series with the general formula $\mathrm{A}_{2} \mathrm{O} \cdot n \mathrm{TiO}_{2}(\mathrm{~A}=$ alkali metal; $0<n<7)$ has been suggested, giving layered structures with $n$ equal to the number of edgesharing octahedra in the ribbons forming the layers [7]. E.g. $\mathrm{K}_{2} \mathrm{Ti}_{4} \mathrm{O}_{9}$ would be an example of an $n=4$ member.

To our knowledge, no example of the $n=2$ structure has been characterized in this family. A polymorph of $\mathrm{K}_{2} \mathrm{Ti}_{2} \mathrm{O}_{5}$, with a different structure, has been reported though [16].

We therefore suggest a hypothetical structure of $\mathrm{K}_{2} \mathrm{Ti}_{2} \mathrm{O}_{5}$, as an intermediate in the transformation of $\mathrm{K}_{2} \mathrm{Ti}_{4} \mathrm{O}_{9}$ to $\mathrm{TiO}_{2}(\mathrm{~B})$.

3.5 PROPOSED TRANSFORMATION MECHANISM. - In figure 7 are shown the essential steps in the mechanism, using idealized polyhedra models.

To the left is shown the structure of $\mathrm{K}_{2} \mathrm{Ti}_{4} \mathrm{O}_{9}(n=4)$. Filled and open circles are potassium ions. The broken circles indicate vacant potassium sites, which may be used in the diffusion process. During the hydrolysis step, the potassium is exchanged for $\mathrm{H}_{3} \mathrm{O}^{+}$, maintaining the structure intact [1]. This exchange is easily achieved through the layered nature of the structure, allowing twodimensional diffusion. This is supported by our HREM investigations of hydrolyzed, but not calcined samples, which did not show any signs of voids being formed.

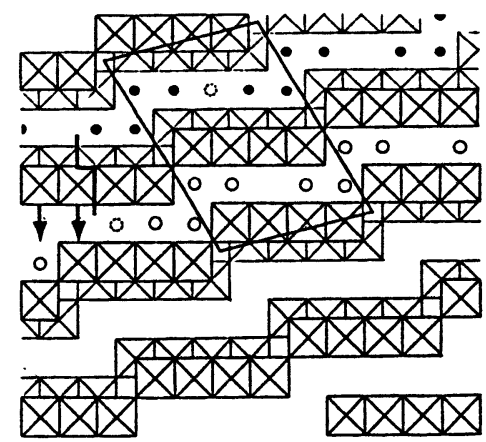

$\mathrm{K}_{2} \mathrm{Ti}_{4} \mathrm{O}_{9}$

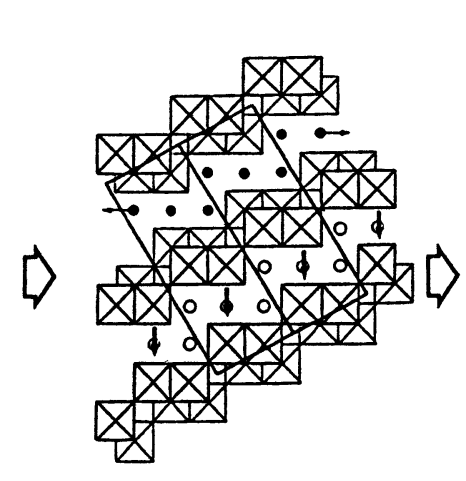

$\mathrm{K}_{2} \mathrm{Ti}_{2} \mathrm{O}_{5}$

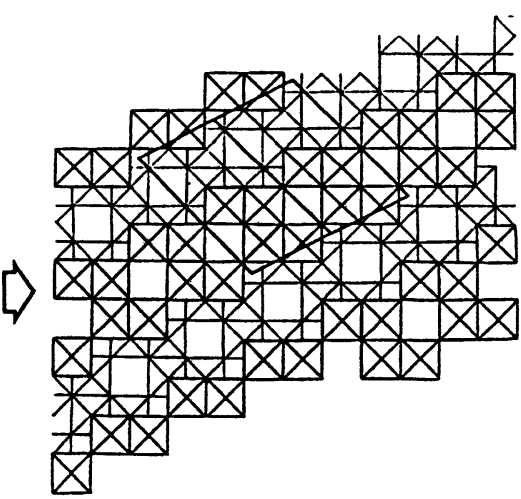

$\mathrm{TiO}_{2}(\mathrm{~B})$

Fig. 7. - Idealized structures, projected along (010).

The quadrupole ribbons are broken into double ribbons, by a shear mechanism, as indicated by the arrows. This forms the hypothetical structure of $\mathrm{K}_{2} \mathrm{Ti}_{2} \mathrm{O}_{5}$, most likely with the potassium replaced by $\mathrm{H}_{3} \mathrm{O}^{+}$, which is available in excess. During calcination, the hydrogen is removed, accompanied by oxygen, forming water. The structure now collapses according to the arrows in the lower part of the middle figure. Finally, $\mathrm{TiO}_{2}(\mathrm{~B})$, to the right, is formed. The microvoids are 
formed by adjacent parts of the structure collapsing in opposite directions, maintaining the outer shape of the crystals.

In the cases when the $\mathrm{K} / \mathrm{Ti}$ ratio was increased, the vacant potassium site in the $\mathrm{K}_{2} \mathrm{Ti}_{4} \mathrm{O}_{9}$ structure was presumably filled, introducing an identical shear, even before the exchange of $\mathrm{K}^{+}$for $\mathrm{H}_{3} \mathrm{O}^{+}$, thus forming the $\mathrm{K}_{2} \mathrm{Ti}_{2} \mathrm{O}_{5}$ structure.

\section{Acknowledgements.}

We gratefully acknowledge prof. Sten Andersson for fruitful discussions on the structures and STEV (the National Energy Administration) for financial support.

\section{References}

[1] MARChand R., Brohan L. and Tournoux M., Mater. Res. Bull. 15 (1980) 1129.

[2] SANATI M. and ANDERSSON A., J. Mol. Catal. 59 (1990) 233.

[3] Tournoux M., Marchand R. and Brohan L., Prog. Solid. St. Chem. 17 (1986) 33-52.

[4] ANDERSSON S. and WADSLEY A.D., Acta. Cryst 15 (1962) 201-206.

[5] Catlow C.R.A., CoRmaCK A.N. and Theobald F., Acta Cryst. B40 (1984) 195-200.

[6] HYDE B.G. and ANDERSSON S., Inorganic Crystal Structures (Wiley-Interscience Publ. New York, 1989).

[7] ANDERSSOn A. and WADSLEY A.D., Acta Cryst. 15 (1962) 194-201.

[8] Verbaere A. and Tournoux M., Bull. Soc. Chim. 4 (1973) 1237-1241.

[9] Brohan L., Verbaere A. and Tournoux M., Mat. Res. Bull. 17 (1982) 355-361.

[10] Theobald F., CaHAla R. and Bernard J., J. Solid State Chem. 17 (1976) 437-438.

[11] Dion M., PIFFORD Y. and TournouX M., J. Inorg. Nucl. Chem. 40 (1978) 917-918.

[12] WALlenberg L.R., SANATI M. and ANDERSSON A., J. Catal 126 (1990) 246-260.

[13] WALLENBERG L.R., ANDERSSON A. and SANATI M., Ultramicroscopy 34 (1990) 33-40.

[14] Wallenberg L.R., Sanati M. and Andersson A., Proc. XII Int. Cong. Electr. Micr. (1990) pp. 234-235.

[15] MiLls E.J. and Wilson D., J. Chem. Soc. 33 (1878) 254.

[16] ANDERSSON S. and WADSLEY A.D., Acta Chem. Scand. 15 (1961) 663-669. 